A Peculiar People Revisited: Demographic Foundations of the Iowa Amish in the $21^{\text {st }}$ Century - Cooksey and Donnermeyer

\title{
A Peculiar People Revisited: Demographic Foundations of the Iowa Amish in the $21^{\text {st }}$ Century ${ }^{1}$
}

Elizabeth C. Cooksey ${ }^{2}$

Professor, Department of Sociology, and

Associate Director, Center for Human Resource Research

The Ohio State University

Joseph F. Donnermeyer

Professor of Rural Sociology

School of Environment and Natural Resources

The Ohio State University

\begin{abstract}
This article describes the demographic foundations of the Amish in Iowa. We note that since the publication of "A Peculiar People" by Dorothy and Elmer Schwieder in 1975 (with an updated version in 2009) the demographic dynamics of the Amish have changed little. They remain a high fertility group, and, when coupled with increases in their retention of daughters and sons in the Amish faith, the Amish are currently experiencing rapid population increase and settlement growth. In turn, the occupational base of the Amish has become more diverse and less reliant on agriculture. We observe that the first or founding families for new settlements in Iowa come equally from outside of Iowa and older settlements within the Hawkeye state.
\end{abstract}

Keywords: settlement, community, migration, fertility, Amish, Iowa 
Journal of Amish and Plain Anabaptist Studies, Volume 1, Issue 1 (April), 2013

\section{Introduction}

In 1975, Dorothy and Elmer Schwieder published “A Peculiar People, Iowa's Old Order Amish" where the term "peculiar" was used in the biblical sense of the word to mean "particular" or "special," rather than today's more common understanding of "strange" or "eccentric." In 2009, with the addition of an essay that includes updates from the 2004 Iowa Amish Directory by Thomas Morain, the book was re-issued by the University of Iowa Press (Schwieder and Schwieder 2009). In both, the authors emphasize that although the Amish way of life may seem strange or eccentric to outsiders, as it says in I Peter 2:9:

But ye are a chosen generation, a royal priesthood, an holy nation, a peculiar people; that ye should shew forth the praises of him who hath called you out of darkness into his marvelous light (King James Bible).

In this paper, we revisit the Iowa Amish approximately 30 plus years after the 1975 edition of the Schwieders' book, using published data from the 2004 and 2009 Iowa Amish directories along with public information from Amish weekly and monthly newspapers: The Budget, published in Sugarcreek Ohio, The Ambassador that comes out of Lancaster, Pennsylvania, and The Diary from Gordonville, Pennsylvania. During this period, America as a whole witnessed massive social, cultural, and demographic shifts. Microsoft was founded in the same year as the Schwieders published their book. Since then we have not only been able to watch world events such as the destruction of the Berlin wall, the collapse of the Soviet Union and the inauguration of the first African American President of the United States on television screens in our own homes, but with the exponential growth of the internet since the 1990s, we can now watch world events unfold wherever we may be on our laptops, iPads, and smart phones. The first Star Wars movie was released in 1977, Rap entered the music scene in the mid-1980s, a NASA spacecraft landed on Mars in 1997, and Facebook was launched in 2004.

Against this cultural backdrop of rapid change, the United States has also witnessed a series of social and demographic changes. The legalization of abortion with the passing of Roe v. Wade in 1973 was a cornerstone of the second wave of feminism that rolled on throughout the 1970s. During the 1980s and 1990s American women continued to push for legislation such as the Equal Rights Amendment, maintained their quest for higher education in ever growing numbers, and increasingly entered the labor market, regardless of marital and maternal status and despite economic booms and busts. In 1970, just over 35 percent of women worked for pay but by 2000, this figure 


\section{A Peculiar People Revisited: Demographic Foundations of the Iowa Amish in the $21^{\text {st }}$ Century - Cooksey and Donnermeyer}

stood at 60 percent (Costa 2000). In 1980 the median age at marriage for women was 22 and the median age at first birth, 22.5 years. By 2009 these figures had risen to 26 and 25 years respectively (Arroyo et al. 2013). Fertility rates have also converged for Latina, black, white, and Asian women, and the United States now has an overall fertility rate that falls below the population replacement level (i.e., when annual birth rates equal annual death rates).

The Amish, living in close proximity to their non-Amish neighbors, are not ignorant of the transformations occurring in the world around them. However, through their strict adherence to a rural-based lifestyle that incorporates a continued reliance on the horse and buggy for local transportation and hence one that also compels them to live near and under the watchful eyes of each other, maintenance of their Pennsylvania German dialect, distinctive patterns of dress, promotion of in-group marriage patterns, their own system of education through age 14 only, and a congregational style of church rule decision-making, they continue to maintain their communities as socially and culturally distinct from the mainstream influences of American life that surrounds them (Ericksen et al. 1979; Hostetler 1993; Donnermeyer et al. 2000). They may live "in the world" but they are not "of the world," and Amish communities or settlements remain highly cohesive, displaying a slower way of life.

But despite these distinctive outward signs, have the Amish really remained untouched by the world that exists just outside the boundaries of the church districts within which they reside? How might they have been impacted by the economic ups and downs that have taken place since the early 1970s? Are the same trends of later marriage and later childbearing that we find in the larger population also to be seen among the Amish? Has the high fertility and large size of Amish families promoted a desire for fewer births in more recent cohorts, or are the Amish finding their own ways to continue to view children as "Blessings from God" and persist in favoring large families? These are questions we address in this paper.

\section{Patterns of Fertility and Marriage}

With strong traditional norms that favor large families, and church doctrine that opposes contraception (Dorsten 1999), the Amish, like other pronatalist populations such as the Hutterites and the Mennonites, have traditionally been characterized by an early age at marriage and much higher levels of fertility than the general US population (Ericksen 1979; Hurd 2006). As presented in Table 1 below, the 2003 Directory of Iowa Amish provides data on 943 women born prior to 1986 who were either living or 
who had died but whose husband was still alive. Slightly over four percent of the 951 households (40 women) had never married and were listed as single female households. Of the remaining 911 households, nearly 96 percent of the husbands were still alive. It is typical in Amish directories for the household to be listed under the name of the male, even when he is deceased, until his surviving spouse remarries. In the Iowa directory, we found 29 "married couple" households, or 3.2 percent, in which the female was actually a widow. Finally, eight households were comprised of single males who had never married.

Table 1: Summary of Households and Persons in the 2003 Iowa Amish Directory

\begin{tabular}{|l|c|c|}
\hline \multicolumn{1}{|c|}{ Description } & Frequency & Percent \\
\hline Never married/single female households & 40 & 4.2 \\
\hline Male-headed households & 911 & 95.8 \\
\hline Total Households & 951 & 100.0 \\
\hline \multicolumn{2}{|c|}{} \\
\hline Married couples: Male still alive & 874 & 95.9 \\
\hline Married couples: Male deceased & 29 & 3.2 \\
\hline Never married/single male households & 8 & 0.9 \\
\hline Total: Male-headed households & 911 & 100.0 \\
\hline
\end{tabular}

From these directory data we calculated that the median age of first marriage of women born prior to 1945 was around 22.5 years and just under 14 percent were unmarried at age 30. In contrast, among women born between 1945 and 1964, fifty percent were married by age 21.5 and only four percent were unmarried by age 30 . Among the most recent cohorts of women born between 1965 and 1985, although the median age at first marriage had increased slightly to 22 years, all but one percent had married by age 30 .

Shadowing a movement towards earlier and, more importantly, nearly universal marriage, fertility levels have also changed across cohorts. As we show in Figure 1, teenage childbearing is almost non-existent for any of the three groups of women. Comparing the date of birth for a first child with a date of marriage we find that almost 75 percent of women either bore or conceived their first child within eight to 12 months after they married and childbearing therefore begins in the early twenties. Although the most recent birth cohorts of women had their first child at a slightly later age than their older peers, once started they had a rapid pace of moving to motherhood so that by their 


\section{A Peculiar People Revisited: Demographic Foundations of the Iowa Amish in the $21^{\text {st }}$ Century - Cooksey and Donnermeyer}

mid-twenties they had a higher percentage of mothers than the two older cohorts. By age 30 just over 95 percent of the youngest group have had at least one child. In contrast, among women born between 1945 and 1964, 87 percent were mothers by age 30 and among the oldest women born prior to 1945, only 79 percent of women had had a first child by age 30 . There is clearly a rapid pace of childbearing in the early twenties across all birth cohorts which is in keeping with a population that has early marriage and does not practice birth control.

Figure 1: Percent Iowa Amish Women with a First Birth (by Age)

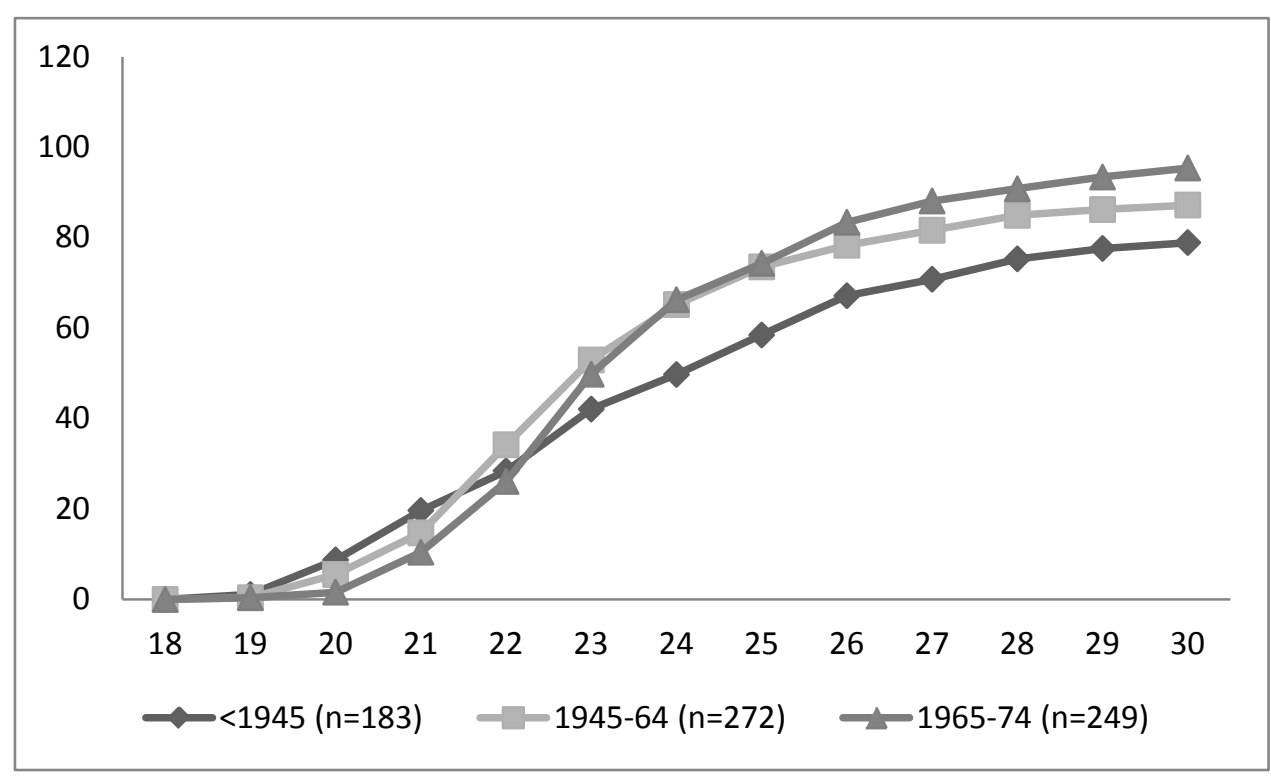

These figures only refer to the timing of first births, however, and although early childbearing tends to be associated with larger numbers of children born, they tell us nothing about total fertility or completed family size. Since these data were collected in 2003, the oldest cohort of women had clearly finished childbearing. Our calculations show that of this group of oldest women, just over 17 percent remained childless and 30 percent had ten or more children. Most, but not all members of the middle cohort had also aged past the end of their childbearing years and of this group only seven percent reported having had no children and 44 percent reported having given birth to ten or more children. The youngest cohorts had yet to complete their fertility by the time the Iowa Directory was published in 2004, but less than three percent of these 249 women in their late twenties and thirties were still childless. Further, whereas completed family size for all women in Iowa who had been born between 1945 and 1954 averaged 2.14 births (Gibson 2012), Iowa Amish women have continued to have six to seven children 
Journal of Amish and Plain Anabaptist Studies, Volume 1, Issue 1 (April), 2013

on average regardless of birth cohort, with some families having as many as 18 children.

Such high levels of fertility have also been publicly noted by members of the Amish community too, as Amishman Herman E. Stutzman from Kenton, OH, wrote in The Diary in 1997:

Recently I had been taking more notice in the large lists of births that are reported in The Diary. Between the last two issues, June and July, there are approximately 1,000 births listed for only two months! Will that be an average for the whole year? Can we imagine 6,000 Amish babies born in one year? That would produce 3,000 married couples or at least 100 new church districts. It will be approximately twenty years before these babies now will be getting married. Will the increase rate continue? If so, these figures will be so mind-boggling (Herman E. Stutzman, Kenton, $\mathrm{OH}$, August 1997).

As a consequence of their high fertility, the rate of population growth among the Amish over the past 100 years has been very rapid. Further, rates of leaving the faith have dropped considerably over time to levels that are quite low today (Wasao and Donnermeyer 1996; Greska and Korbin 2002). Unfortunately, Iowa Directory data for Amish youth does not include information on baptism, but Directories on Amish in other areas of the United States do. Using data from the 2000 Ohio Directory that covers the largest Amish settlement in the United States (Holmes County and vicinity), we calculated that the percentage of Amish youth leaving the faith has been more than halved from approximately 30\% for those youth born prior to 1945 to less than $15 \%$ among those born between 1966 and 1975.

The higher rates of baptism for more recent birth cohorts is partly explained by the fact that younger Amish have grown up with a greater degree of difference between them and their "English" neighbors than did the cohorts before them. When most of the population was rural, it was easier to leave the Amish faith and perhaps join a rural Mennonite church instead. Today's youth face a much wider divide between their upbringing and those of their English counterparts. It is more difficult for the Amish youth of today who wish to leave their communities to survive in the outside world with only an eighth grade education than it was a generation or more ago. The bottom line is that as a result of early and near universal marriage, high fertility and low rates of leaving the faith, the Amish population is consequently doubling nearly every twenty years. In comparison, even with the benefit of migration, the US population was half its current size of 315 million 61 years ago in 1952 (Census Bureau 2012). 


\section{A Peculiar People Revisited: Demographic Foundations of the Iowa Amish in the $21^{\text {st }}$ Century - Cooksey and Donnermeyer}

\section{Occupational Change}

The United States as a whole has witnessed major shifts in occupational structure since the early 1970s. A report put out by the Carsey Institute in 2008 (Smith 2007) shows how the paid employment of men ages 16 to 64 living in rural areas declined from 92 percent in 1970 to 80 percent in 2000 as men's jobs in traditional rural industries such as agriculture, natural resource extraction. and manufacturing declined (Lobao and Meyer 2001). As the service sector expanded, creating opportunities for women at the same time as households struggled to make ends meet (Lobao and Meyer 1995; Falk and Lobao 2003), the paid employment of rural women in the same age range rose from $57 \%$ to $75 \%$ although these figures mask stark educational differences as only approximately 50 percent of women with less than a high school education were working during each decade. Even women living in communities where strict gender roles are followed became primary wage earners as men's jobs disappeared (Tickamyer and Henderson 2003).

Occupational change has occurred within Amish communities too but in different ways and for different reasons. First, Amish communities have not witnessed a move toward female paid employment as Amish women continue to fulfill their traditional roles as wife and mother, taking care of the home; raising their children; making their clothes; and growing, storing, canning, and cooking the food for their families. In this manner they fulfill an economic role in their families but more of a home grown one. Amish men, have also not fallen prey to the booms and busts of the larger U.S. economy as their traditional farming ways have always been self-reliant, self-sufficient, and emphasized providing for the immediate family rather than producing economic profit. This does not mean that their traditional farming lifestyle has remained intact, however, as their high levels of fertility and youthful, rapidly growing population has created a scarcity of available land to farm. Two different pathways have been taken to solve this problem.

First is a diversification of occupations. When describing the Iowa Amish in the mid-1970s, Dorothy and Elmer Schwieder observed that:

A paramount consideration of the Amish is commitment to the soil, both in terms of its proper use as well as reliance upon it for their livelihood. The Amish believe that the only acceptable occupation is farming. One reason is, of course that they have never known any other environment, but more important they believe that as farmers they live closer to God 
Journal of Amish and Plain Anabaptist Studies, Volume 1, Issue 1 (April), 2013

and their rural way of life allows them to better serve Him (Schwieder and Schwieder, 1975, p. 23).

From the 2004 Iowa directory occupational listings and the Morain, Schwieder and Schwider (2009) review of occupations from the same 2004 edition, we find that approximately 50 percent of male householders still farm, although some of these farmers also have a second occupation listed. Close to 25 percent are involved in carpentry or work in lumber yards or sawmills, and about 17 percent engage in a variety of other occupations from harness making to rug making and cheese making. An entry in the 2004 directory concerning the history of the Milton settlement in the southern county of Van Buren notes that

There are quite a few businesses in the area. Eldon Yoder started a furniture shop. Business grew and now Leroy Borntrager and Daniel Wagler also have furniture shops. Leroy Mullett started a nylon business. It has grown until he has Melvin Hostetler, Melvin Miller, Reuben Hostetler and Chester Borntragers sewing for him. Chrissie Hochstetler took on his dads repair shop and buggy making business. Oren Yoder owns a sawmill where about a dozen men are employed. Mrs. Fred Yoder started up the dry goods store...... Henry Mullet Jr has a clock making and repairing shop. Menno Hostetler has a shop where he repairs old items, but also makes new furniture (pp. 222-223).

In Figure 2 we present occupational data for three different sets of birth cohorts and striking from the graphs is the steep drop in the percentage of men reporting farming between men born prior to 1970 of which 60 to 70 percent were farmers, and of those born after 1970, the proportion decreases to 38 percent. Showing an almost fourfold increase are businesses involving the sawing and milling of wood and carpentry including furniture making.

Updated statistics from the 2009 Iowa Directory (Keim 2009), which includes all but the five settlements founded since then (and the multi-state settlement of Granger, Minnesota/Cresco, Iowa), the occupational shift continues. Out of 935 households for which a male's (of any age) occupation was listed, only 36.7 percent were solely in some form of agriculture (including greenhouse operations), and another 21 percent were listed as dual occupation, such as farmer/woodworker or farmer/welder. Nearly 24 percent were in carpentry, woodworking, or occupations requiring carpentry skills, and another 18.8 percent were in occupations other than agriculture or carpentry, ranging from working in sawmills/lumberyards to vinyl siding installation. 
A Peculiar People Revisited: Demographic Foundations of the Iowa Amish in the $21^{\text {st }}$ Century - Cooksey and Donnermeyer

Figure 2: Occupations of Iowa Male Householders in 2003 by Birth Cohort

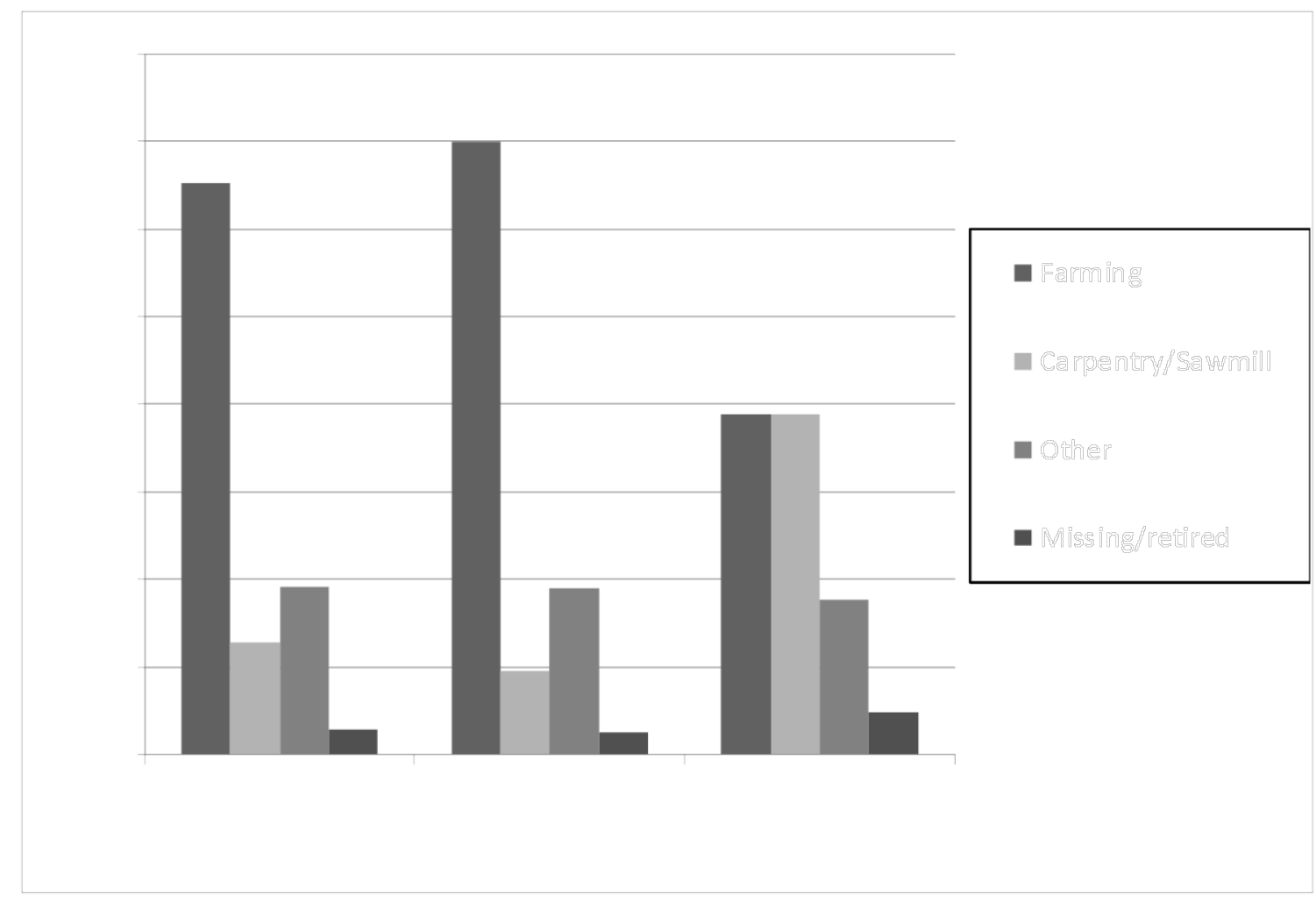

\section{Patterns of Migration}

A second way in which the Amish have overcome their problems of insufficient farmland in their home communities has been to move. There are, of course, many other reasons why individuals choose to move including wishing to be closer to relatives, a desire to move to a stricter or less conservative church district, or getting away from burgeoning tourism, but moving to an area that has affordable land to farm remains a prime reason.

From historical accounts written in the Iowa Directories and information gleaned from Amish written news sources, we can not only map the location of new communities but also connect them back to the place of origin of their founding families. News accounts additionally include valuable anecdotal information relating to the search for appropriate locations for new communities, motivations for establishing new communities and why certain families move there, plus events related to building 
the economic, social, and religious infrastructure necessary to sustain new Amish settlements over time.

Figure 3 maps all 22 settlements located in Iowa by the beginning of 2013. In 1950, only two Amish communities existed in Iowa. By 1975, there were five surviving communities and by 2000 four more had been added. However, the real growth has occurred after this and during the twenty-first century as by the beginning of 2013, were 22 settlements and 56 church districts. That's 12 new settlements in a 12-year period!

Two settlements in Figure 3 lie on a state border. To the south is the Lamoni/Davis City settlement that spills into Missouri. About one in four members of this settlement live in the "Show Me" state, with the reminder in Iowa. To the north is the Granger/Cresco settlement. It is considered a Minnesota settlement and not counted among the 22 for Iowa, even though about 55 percent (out of a population of nearly 300) of the Amish lives in the Hawkeye State. The is due to the fact that the settlement's first families bought land on the north side of the state line (Keim 2009). Altogether, after subtracting out the Minnesotans and Missorians, there are nearly 7,500 Amish people calling Iowa their home by the end of 2012. About 2,900 were adult, baptized members and the remainder were children and adolescents who had not yet made a decision to be baptized into the Amish faith.

Not all Amish settlements grow successfully after their establishment. In the United States as a whole, 85 Amish settlements went extinct in the roughly forty years between 1961 and 2003 (Luthy 1986). However, only one settlement - Maquoketa in far eastern Jackson County - established after 1860 has gone extinct in Iowa.

The geographic spread of Amish settlements in Iowa follow a rough horseshoe shaped pattern along the northeastern tier of counties with Minnesota, then curving through a number of eastern counties, and extending westward through two tiers of southern counties - from Van Buren to Ringgold - close to Missouri. This is where the cheapest land is available to buy. The most centrally located Amish settlement is also the oldest and largest extant settlement, namely, Kalona. It was founded in 1846, the same year Iowa was admitted to the union, when land prices were different from today. According to an article printed in October 2004 in The Gazette (Iowa), the price of Iowa farmland had increased 14.4 percent over the previous year. In the Kalona community, where farming still predominates, an Amish farmer bought a 37.8 acre farm with house and outbuildings in July 2004 for \$7,892 per acre. In contrast, in the 


\section{A Peculiar People Revisited: Demographic Foundations of the Iowa Amish in the $21^{\text {st }}$ Century - Cooksey and Donnermeyer}

Figure 3: Extant and Extinct Amish Settlements in Iowa (year founded and number of church districts)

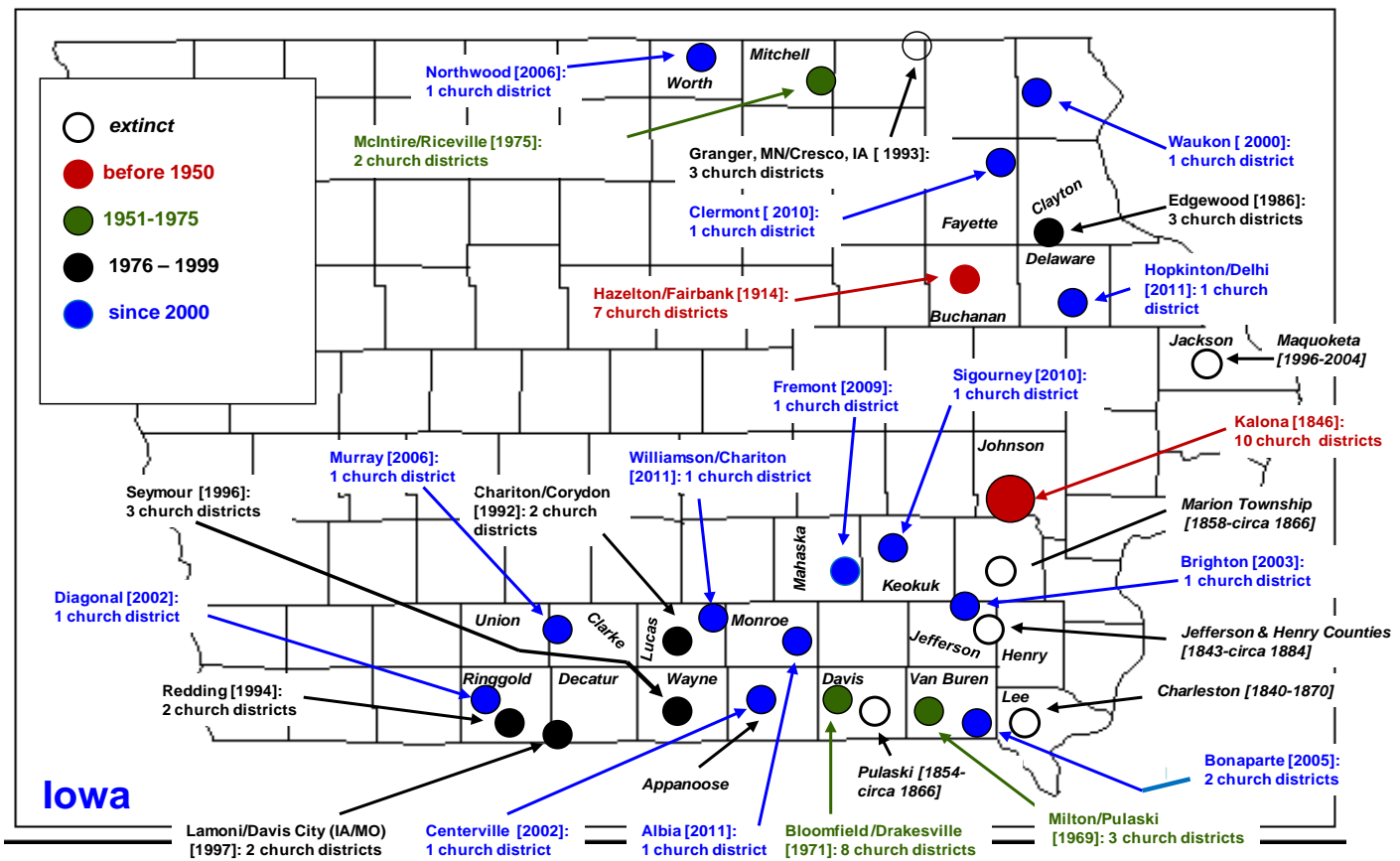

Bloomfield/Drakesville Amish community, second only to Kalona in size, but located in Davis County of southern Iowa, sales had been in the range of only $\$ 2,000$ per acre.

In Figure 4 we include information about the origins of the first families to each of the 12 communities founded in Iowa since 2000. We are unsure of the origin of first families to the Fremont settlement in Mahaska County, but of the other 11, there is a near even split, with five settlements' founders coming from outside the state, and six settlements started by families from settlements within Iowa.

The outside sources helping to spur Amish settlement growth in Iowa are not Indiana, Ohio or Pennsylvania, but the neighboring states of Minnesota and Wisconsin to the north, and Missouri to the south, plus some help from Michigan for the Bonaparte settlement in southeast Iowa. Internally, the Kalona settlement was instrumental in starting two new settlements only a short distance away. Additionally, the Edgewood settlement helped start up to settlements (Hopkinton/Delhi and Clermont) in adjoining counties. Further, the far north settlement of McIntire/Riceville was the point of origin for families who helped to found the nearby Northwood settlement and the Diagonal settlement on the other side of the state. Finally, families 
Journal of Amish and Plain Anabaptist Studies, Volume 1, Issue 1 (April), 2013

from the Chariton/Corydon settlement in Lucas County were the first to move to the Centerville settlement in Appanoose County on the border with Missouri.

The Brighton settlement was established as a daughter community of the Old Order community of Kalona. The quote below, provided in the Iowa Directory (2004, p. 52), explains their reasoning behind starting this new community in Brighton and also supplies some information about the way in which a new community looks for a suitable location:

For quite some time there has been a concern in the Kalona, IA community to start a daughter settlement hoping to maintain our family life style of raising our families on a farm. With land prices in the Kalona area skyrocketing, hopes for cheaper land was being sought. In 1994, a group of men toured the Brighton area, but for various reasons it was decided not to buy land at that time...... Then in the summer of 2002 another party went land shopping.

Sending out a land party, or a group of men, usually from the same community, to search for land for enough families to live close together is a common way to start the process of new community formation. But there is also a lot of movement by individuals between established communities as this next directory passage about the Milton community that was begun in 1969 illustrates (Miller 2004, p. 222):

Henry B. Mullett and son Henry Jr. moved on February 25, 1969. The other families moved in soon after..... Early in 1970 several more families moved here. Minister David Stutzman, Eli Yoders and Jacob Beachys moved here from Arthur, Illinois. Jacob arrived in an April snowstorm. Minister Menno Hostetler moved in from Jamesport, Missouri. In 1971, 13 more families moved in. The settlement grew rapidly. By 1979, 10 years after the settlement started, 73 families had lived there. By 1974 some started leaving. In 1983 quite a few families moved out to start a new settlement in Wautoma, Wisconsin. Since then families have been moving in and out of the settlement. A total of 165 to 170 families have lived here some time or other. 59 families make their homes here at present. 


\section{Figure 4: Place of Origin of First Families to New Settlements (founded since 2000) in Iowa}

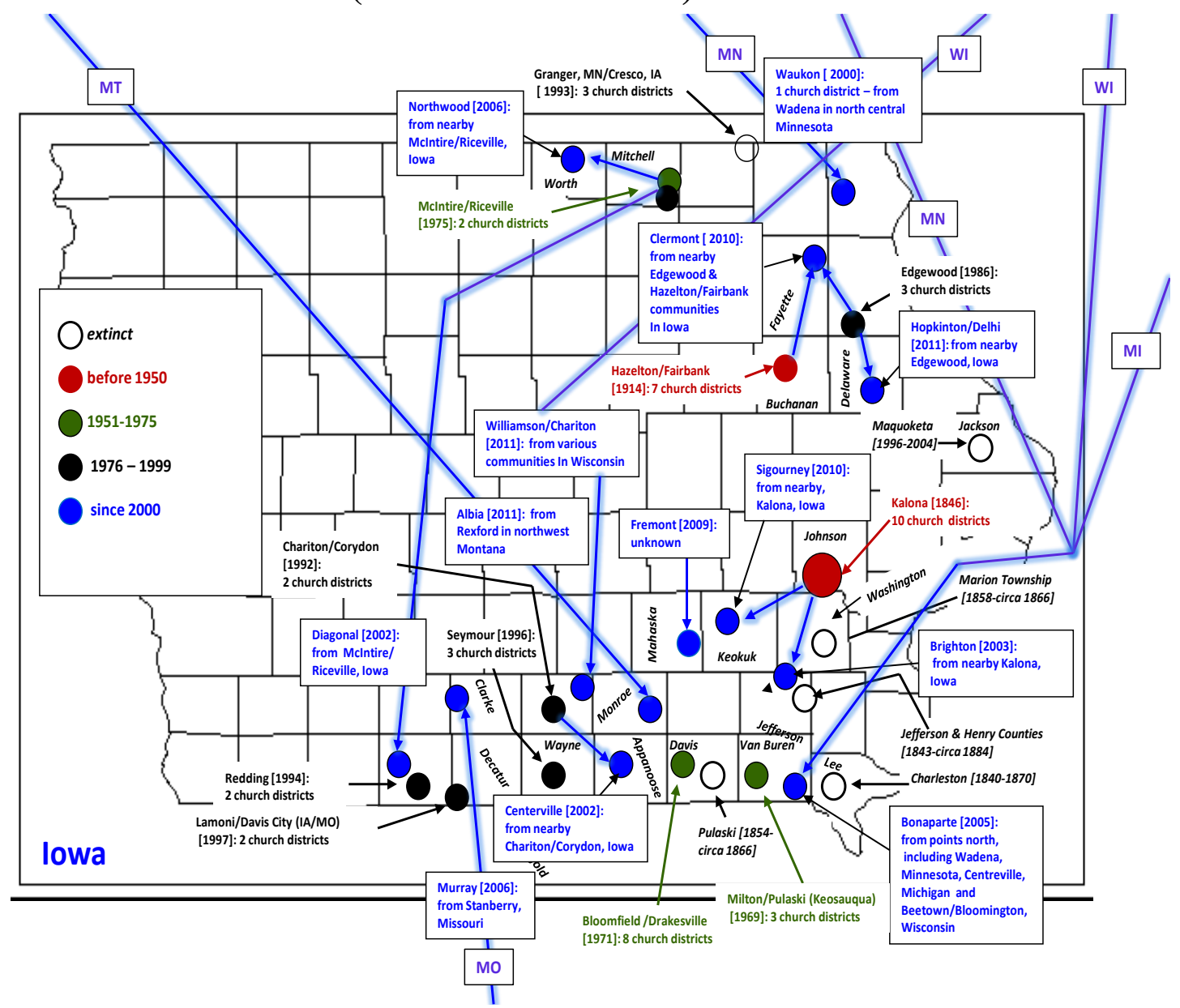

This quote illustrates the tremendous fluidity that is simply part of Amish life. In the face of difficult times, either as a result of their initial religious persecution as Anabaptists back in the seventeenth century, or today, confronted by increasing tourism which challenges their desire to live a peaceful existence away from the hubbub of mainstream U.S.A., an inability to afford or make a living from the land available locally, or disagreements about church discipline, leadership and perceived tolerance of inappropriate teenage behavior - the Amish have always seen migration as an option to pursue (Luthy 1994). And although the Amish as a rural population may be viewed as being tied to the land, they are not tied to particular parcels of land. Whether it is individuals, families, small groups, or whole communities that move, their selfsufficiency as communities held together by strong bonds of fellowship and strongly 
Journal of Amish and Plain Anabaptist Studies, Volume 1, Issue 1 (April), 2013

self-prescribed rules for everyday living, ensure that migration functions as a safety valve rather than as a cause of schism.

\section{Summary}

In recent decades, the United States as a whole has witnessed tremendous social, economic and cultural change. Although the Amish purposely choose to maintain a separate and distinctive way of living from their "English" neighbors in the broader outside world that surrounds their communities, many of these changes, especially those associated with new, fast, and widespread forms of communication, have both posed a threat to their relative isolation and have had the potential to impact the ways in which they live their everyday lives. However, they are not an unchanging nor a homogeneous population and from the sources of data we have examined in this paper, the Amish appear to have adapted to, as well as resisted, these forces of change. At least in terms of their demographic patterns, the Iowa Amish in the new millennium appear very little changed from the Iowa Amish described by the Schweiders (1975) up through the early 1970s.

Both the original 1975 edition and the 2009 re-issue of "A Peculiar People” observed that a willingness to move by the Amish provides a safety valve for all types of economic problems or personal discontent. This remains true today. When faced with a rapidly increasing rate of population growth and rising land costs, they move to more affordable areas and/or diversify their occupations. Further, the very real changes in occupational structure that have occurred over the past few decades do not appear to have impacted patterns of marriage or childbearing. Like their parents, grandparents, and great grandparents before them, the Amish youth of today still marry, and they marry young. They also begin family building at young ages, give birth to many children as did their mothers and grandmothers, and increasingly are less likely to be childless at age 30 .

These trends herald a continued rapid rate of population growth for the Amish as the twenty first century continues, both in Iowa and across the continental United States, and will no doubt precipitate future social and economic change within Amish society. However, lessons of the recent past, as illustrated by the Iowa experience, also suggest that there is sufficient flexibility built into the rules of everyday Amish living so that relatively minor adjustments can be made in order to maintain the basic institutions and structure that have characterized the Amish since their formation over 300 years ago. 
A Peculiar People Revisited: Demographic Foundations of the Iowa Amish in the $21^{\text {st }}$ Century - Cooksey and Donnermeyer

\section{Endnotes}

${ }^{1}$ Support provided by the National Institute of Child Health and Human Development and the Ohio Agricultural Research and Development Center.

${ }^{2}$ For more information, contact Elizabeth Cooksey, Professor, Department of Sociology and Associate Director of the Center for Human Resource Research, Room 100, 921

Chatham Lane, The Ohio State University, Columbus, Ohio 43221. Office - $614422-$ 7333; E-mail-Cooksey.1@osu.edu. 
Journal of Amish and Plain Anabaptist Studies, Volume 1, Issue 1 (April), 2013

\section{References}

Arroyo, Julia, Krista K. Payne, Susan L. Brown, and Wendy D. Manning. 2012. "Crossover at Median Age at First Marriage and First Birth: Thirty Years of Change.” Family Profile-12-03, National Center for Marriage and Family Research. Retrieved from http://ncfrm.bgsu.pdf.family_profiles/file107893.pdf

Costa, Dora L. 2000. "From Mill Town to Board Room: The Rise of Women's Paid Labor.” Journal of Economic Perspectives 14(4):101-122

Donnermeyer, Joseph F., George M. Kreps, and Marty W. Kreps. 2000. Lessons for Living: A Practical Approach to Daily Life from the Amish Community. Walnut Creek, OH: Carlisle Printing Company.

Dorsten, Lawrence E. 1999. "Fertility Decline in a U.S. Population Favoring Large Families: A Hazard-Model Analysis of the Effect of Sib Death on Amish Fertility.” Population Research and Policy Review 18:323-338.

Ericksen, Julia A., Eugene P. Ericksen, John A. Hostetler, and Gertrude E. Huntington. 1979. "Fertility Patterns and Trends among the Old Order Amish.” Population Studies 33(2):255-276.

Falk, William, and Linda Lobao. 2003. "Who Benefits from Economic Restructuring? Lessons from the Past, Challenges for the Future?” Pp. 152-165 in Challenges for Rural America in the Twenty-First Century, edited by David Brown and Lou Swanson. University Park, PA: Pennsylvania State University Press.

Gibson, Campbell. “American Demographic History Chartbook 1790-2010, Figure A81.” http://www.demographicchartbook.com

Greska, Lawrence P., and Jill E. Korbin. 2002. "Key Decisions in the Lives of the Old Order Amish: Joining the Church and Migrating to another Settlement." Mennonite Quarterly Review 76:373-398.

Hostetler, John A. 1993. Amish Society. Baltimore: Johns Hopkins University Press.

Hurd, James P. 2006. "The Shape of High Fertility in a Traditional Mennonite Population.” Annals of Human Biology 35(5-6):557-569. 


\section{A Peculiar People Revisited: Demographic Foundations of the Iowa Amish in the $21^{\text {st }}$ Century - Cooksey and Donnermeyer}

Lobao, Linda, and Kay Meyer. 1995. “Economic Decline, Gender, and Labor Flexibility in Family-Based Enterprises: Midwestern Farming in the 1980s.” Social Forces 74(2):575-608.

Lobao, Linda, and Kay Meyer. 2001. "The Great Agricultural Transition: Crisis, Change, and Social Consequences of Twentieth Century U.S. Farming.” Annual Review of Sociology 27:103-124.

Luthy, David. 1986. The Amish in America: Settlements that Failed 1840-1960. LaGrange, IN: Pathway Publishers

Luthy, David. 1994. “Amish Migration Patterns: 1972-1992.” Pp. 243-260 in The Amish Struggle with Modernity, edited by Donald B. Kraybill and Marc A. Olshan. Baltimore: The Johns Hopkins University Press.

Miller, Devon (ed.). 2004. Iowa Amish Directory. Millersburg: Abana Books.

Schwieder, Elmer and Dorothy Schwieder. 1975. A Peculiar People: Iowa's Old Order Amish. Ames, IA: Iowa State University Press.

Schwieder, Elmer and Dorothy Schwieder. 2009. A Peculiar People: Iowa's Old Order Amish. An Expanded Edition, with a new essay by Thomas Morain. Iowa City: University of Iowa Press.

Smith, Kristin. 2008. Working Hard for the Money: Trends in Women's Employment 1970-2007. Reports on Rural America 1(5), Carsey Institute.

Tickamyer, Ann. and D. Henderson. 2003. "Rural Women: New Roles for the New Century?” Pp. 109-117 in Challenges for Rural America in the Twenty-First Century, edited by in David Brown and Lou Swanson. University Park: Pennsylvania State University Press.

Wasao, Samson, and Joseph F. Donnermeyer. 1996. “An Analysis of Factors Related to Parity among the Amish in Northeast Ohio.” Population Studies 50:235-246. 